\title{
Segregation of Plastic Waste from Solid Waste Stream: Bangladesh Perspective
}

\author{
Md Sanuwar Uddin and Mohammad Zoynal Abedin
}

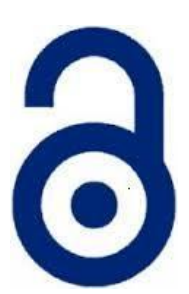

Received: 16 April 2021

Accepted: 22 April 2021

Published: 01 October 2021

Publisher: Deer Hill Publications

(C) 2021 The Author(s)

Creative Commons: CC BY 4.0

\begin{abstract}
Solid waste is an inevitable by-product of human beings, animals and also of industrial-commercial activities. Obviously solid waste creates a greater problem to the environment, if it is not properly managed. Bangladesh being a heavily populated country needs to pay adequate attention to waste management. Waste generation in Bangladesh is increasing because of rapid urbanization and economic development of the country. At present, total solid waste generation in Bangladesh is around 27000 tons/day and in the four important city corporations is about 13,332 tons. Particularly in Dhaka city, it is around 7500 tons/day. This amount is likely to reach about 47000 tons per day in entire Bangladesh and 15000 tons per day for Dhaka city alone by 2030. At present, landfilling is the only method for disposal of heterogeneous waste stream and there are three landfills in Dhaka City. Most of these landfill sites are in open dumps polluting land, water and air. Development of any new landfill site is near to impossible due to land scarcity and increasing of land prices especially in Dhaka City. Improperly disposed waste is posing serious health implications to the people and it may transmit various diseases especially by non-degradable wastes like polythene. Rather, a proper segregation system to recover of resource from plastic wastes can play a very important role in mitigating the difficulties of solid waste that can act as a raw material for product design in Bangladesh too. Therefore, a comprehensive study report followed by a model of plastic waste segregation system for Bangladesh has been highlighted in the paper.
\end{abstract}

Keywords: Solid wastes, Plastic wastes, Segregation, Resource recovery, Product design.

\section{INTRODUCTION}

Management of municipal solid waste (MSW) is a widely discussed topic in the scientific community due to its importance in energy conservation, environmental sustainability, economic growth, safety and so on. In addition, it is now becoming a demanding issue due to the increased rate of industrialization, urbanization, per capita income and change of habits in life pattern of the people [1]. Thereby, waste management (WM) has become one of the key issues across the globe including Bangladesh especially in the mega cities like Dhaka [2]. Besides, volume and varieties of waste stream is also creating tremendous pressure on the disposal capacities, forcing the city authorities continuously to search out for optional and acceptable ways to deal with this demanding issue [3].

Bangladesh being an emerging middle economy country has now a population of about 168 million with a density of around 1400 per square kilometer and is expected to rise up to about 177 million by 2025 . Presently about 21,332 tons per day of solid wastes $(S W)$ are generated in this country. This estimation is projected to be increased up to 47,000 tons per day by 2030 , wherein Dhaka city subsidizes about 6870 tons per day [4]. Dhaka is growing fast into an extended mega city with an enormous population growth rate of 6 percent per year and wastes are being generated at a faster pace due to the rapid growth of industries and population, which possesses a serious threat to the management of MSW [5]. For instance, especially in Dhaka city around 550 tones plastic wastes are accumulated per day [6].

Among the MSWs, plastic wastes seem to be a threat to the environment as it creates toxic gases and parasites like dioxin, forun and pathogens that ultimately leads to the serious degradation of life of the living beings and the environment as well. Especially, plastic wastes seriously contaminate the environment by all means, degrading the

Uddin, M. S. and Abedin, M. Z. 凶

Department of Mechanical Engineering

Dhaka University of Engineering and Technology

Gazipur-1707, Bangladesh.

E-mail: abedin.mzoynal@duet.ac.bd

Reference: Uddin and Abedin (2021). Segregation of Plastic Waste from Solid Wastes: Bangladesh Perspective. International Journal of Engineering Materials and Manufacture, 6(4), 324-331. 
quality of soil, contaminating water body and air. To restore the problem, several researches have been concentrated in the transformation process from plastic waste into useful resources using different technologies.

Though plastic is one of the integral parts of our daily life, it plays vital role for polluting the environment. The more is the usage of the plastic products; the more is the pollution of environment gets. In recent years the plastic consumption has increased manifolds leading to accumulation of plastic waste in large amounts. Therefore, the usage of plastic product is interrelated to the polluted environment affecting human and plant life. Our aim should be towards reducing the plastic product and its usage but if not, then to move to recycling and make its wastage more of a resource. Even if it's not, then the process of segregating the plastics from main waste stream should be strongly practiced. Therefore, a well-thought-out waste management system that would protect human health, natural resources and the environment, requires continual upgradation of the existing waste management system [7].

\section{WASTE SCENARIO IN THE WORLD}

The exponential growth of population, urbanization and development of the social economy, coupled with the improvement of living standards, have increased the amount of MSW generation throughout the world. Figure 1 shows the composition of municipal solid waste in the world where mostly organic waste (46\%) are seen to be generated [3]. A twofold increase in global MSW generation was observed from 2000 through 2010. During 2010, annually global MSW generation was 1.3 billion MT, and by 2025 , it is projected to reach 2.2 billion MT per year and 4.2 billion MT per year by 2050 [4]. Such rapid rise of waste footprint will undoubtedly harm sustainable living style and the local environment (air, water, land) and human health, if not appropriately managed [5]. Rapid population growth and the accompanied factors like profligate industrialization for national economic growth and urbanization causing severe MSW management problems in several cities in developing and underdeveloped countries. Generally, in European countries and Organization for Economic Cooperation and Development (OECD) countries, MSW covers waste from households ( $82 \%$ of total MSW), including bulky waste, waste from commerce and trade, office buildings, institutions, and small businesses, yard and garden waste, street sweepings, the contents of litter containers, and market cleansing waste [6]. The MSW discussed in the paper, excludes the waste from municipal sewage networks and treatment and municipal construction and demolition waste. However, national descriptions, definition of MSW may differ from country to country. In a developing economy like Bangladesh, MSW is generally defined as the waste produced in a municipality. Most of the MSWs generated in developing countries are not segregated and may be either hazardous or non-hazardous. In general, whatsoever be the source of MSW, its impact on the environment and quality of life is mainly related to air, water, and soil contamination. It is also associated with space consumption, odours, and aesthetic prejudice [7].

Several different systems to separate food waste collection for later biological treatment have been implemented in European countries over the last decades. Highly efficient methods based on source-segregation of household food waste exist in Austria, Germany, Sweden, The Netherlands and Spain [8]. However, these systems have in common feature that without households' participation in the initial act of source-segregating, the efficiency is vastly decreased.

\section{WASTE SCENARIO IN BANGLADESH}

In Dhaka, MSW is usually handled and processed by a large informal sector similar to other developing countries. But no separation scheme currently available here. Also, no collection and disposal schemes are available for hazardous wastes. Waste is generally collected by waste collectors who take the waste to the local waste collection point. Then conventional open trucks are used to move the wastes to the landfill site. Waste generation is significantly increased over the decades, and landfills are becoming scarce. A recycling industry runs its scheme to collect wastes. In the scheme, the waste is collected from door to door as well as from the collection point and landfill sites as well.

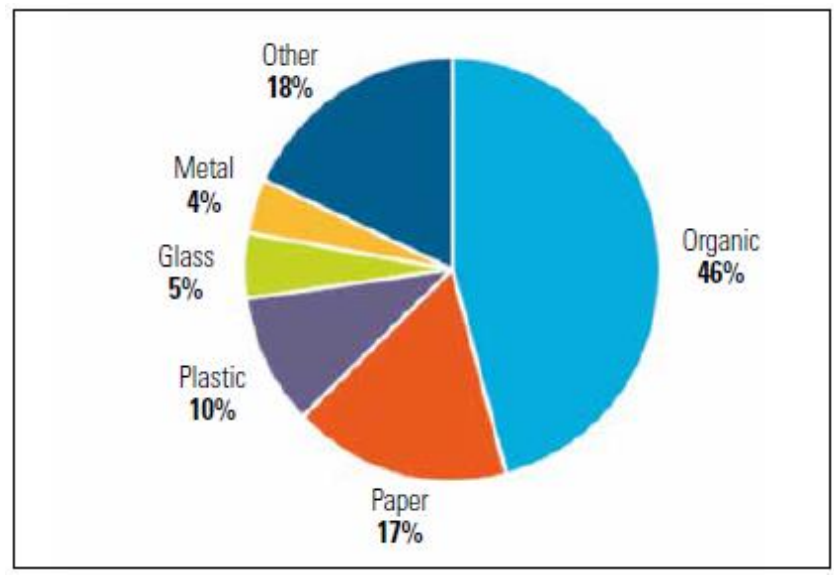

Figure 1: Composition of municipal solid waste [3]. 
As for renewable energy, waste is taken to the treatment site, where these wastes are turned into biogas to produce energy. The Government is working with several NGOs to develop Biogas production plants and established 13,500 Biogas plants [9]. The climate of Bangladesh is also favorable for Biogas production as it needs $35^{\circ} \mathrm{C}$ to produce biogas which is optimum to the average temperature of Bangladesh. The Government, Municipality, Private organization and NCOs are involved to the waste management processes.

Figure 2. depicts a yearly increasing rate of solid wastes generation in Bangladesh from 1985 to the predicted year of 2030 [2]. From the figure, it seen that solid waste generation has been abruptly increasing in Bangladesh after 2015s mainly due to the change in economic income of manpower and increased rate of industrialization in Bangladesh.

Figure 3 depicts the area of land needed for smooth disposal of solid waste in Bangladesh from 1985 up to 2030 [2]. At present there are about 150 hectares of land allotted to accommodate the MSW of all major cities of Bangladesh till 2015. However, unfortunately, no facility has been augmented specialty about number and size of waste disposal areas. Thereby, disposal sites are getting saturated with increased rate of MSW in Bangladesh.

\section{COMPOSITION AND PROPERTIES OF WASTE OF DHAKA CITY IN BANGLADESH}

Majority of MSW in Bangladesh comprises of food wastes which is almost similar to other cities of the world. Figure 4 shows various composition of MSW of Dhaka city. Table 1 shows the state of solid wastes as per category of household, industrial, commercial wastes and at the same time moisture content of the solid wastes. Proximate analysis is done to find the physical properties, and ultimate analysis is done to get the chemical properties.

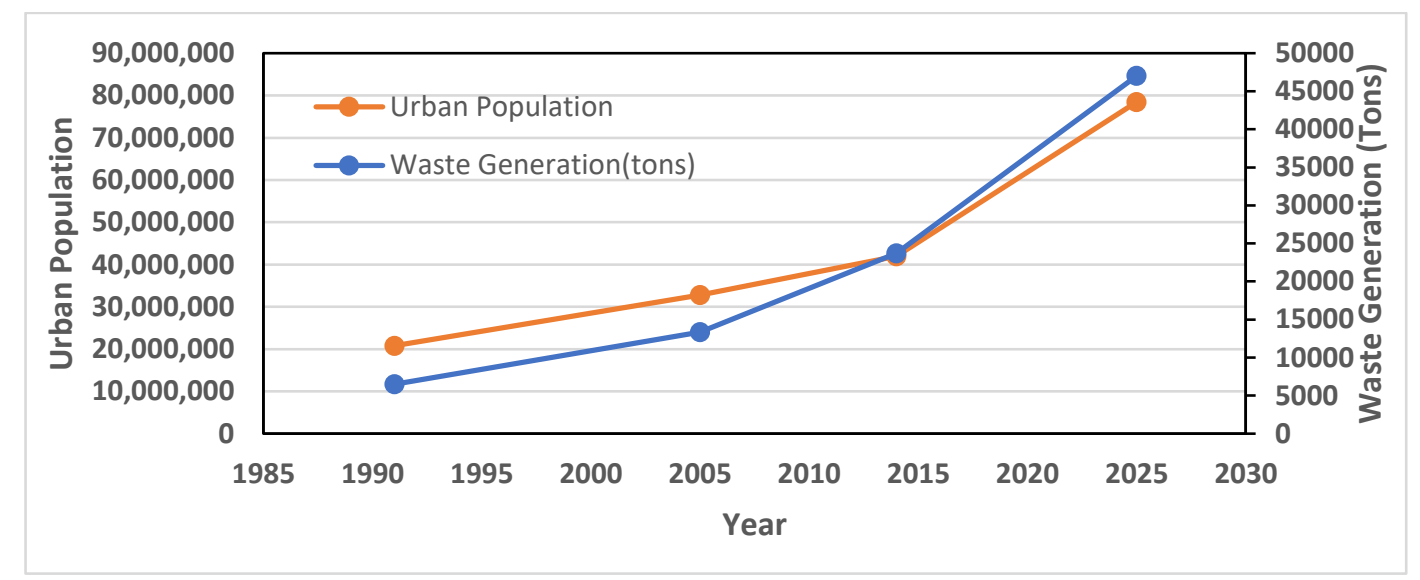

Figure 2: Urban ppopulation and waste generation from 1985 to 2030 for Bangladesh [2].

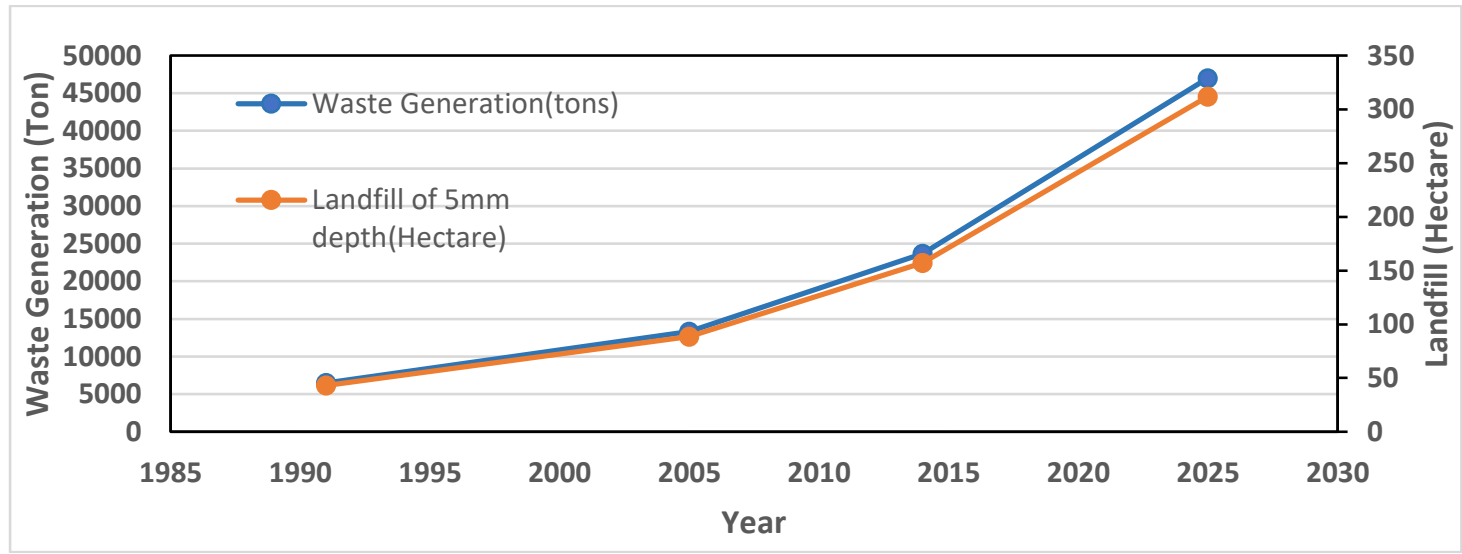

Figure 3: Waste generation in Tons and llandfill area in Hectare in Bangladesh [2]. 


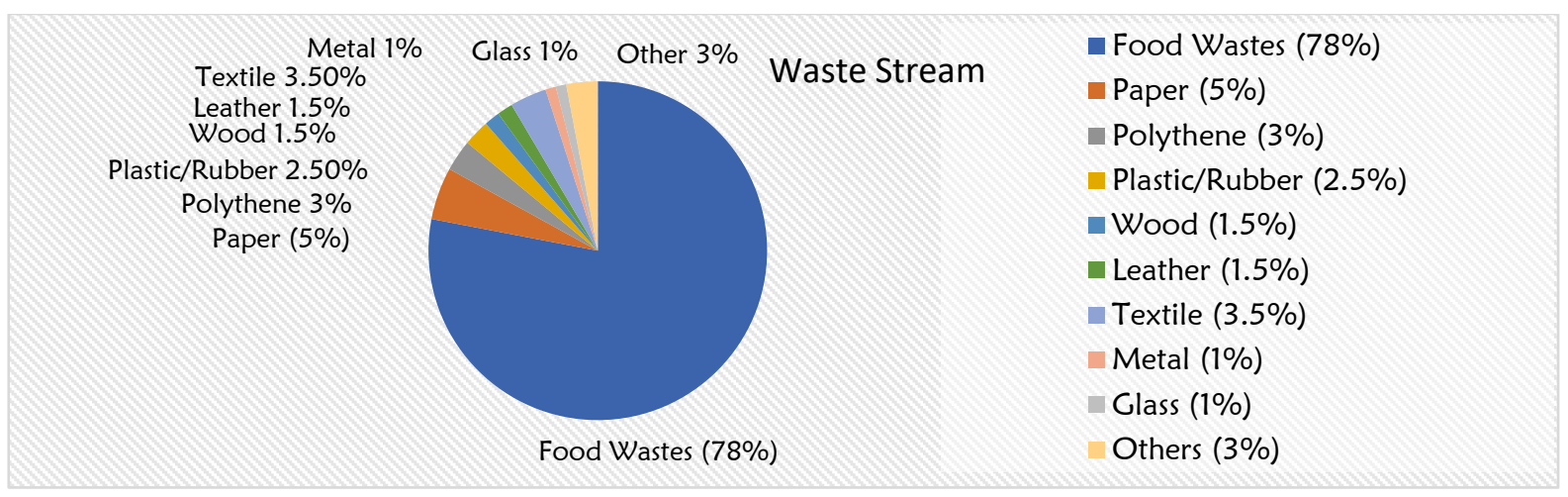

Figure 4: Waste composition of Dhaka City of Bangladesh in 2017.

Table 1: Composition and properties of MSW of Dhaka City in Bangladesh.

\begin{tabular}{|l|c|c|c|}
\hline \multicolumn{1}{|c|}{ Component } & $\begin{array}{c}\text { Residential Waste } \\
\text { By Weight (\%) }\end{array}$ & $\begin{array}{c}\text { Commercial Waste } \\
\text { By Weight (\%) }\end{array}$ & $\begin{array}{c}\text { Industrial Waste } \\
\text { By Weight (\%) }\end{array}$ \\
\hline Food and Vegetable Waste & 59.51 & 62.05 & 26.37 \\
\hline Paper Products & 11.21 & 6.28 & 7.59 \\
\hline Plastics, Rubber and Leather & 17.67 & 4.62 & 6.01 \\
\hline Metals & 0.15 & 0.28 & - \\
\hline Glass and Ceramics & - & 0.37 & 4.32 \\
\hline Garden Wastes, Tree Trimming and Straw & 8.76 & 2.86 & 46.20 \\
\hline Cloths & - & 18.93 & 9.49 \\
\hline Rocks, Dirt and Miscellaneous & 2.30 & 4.62 & 60.00 \\
\hline Moisture Content (\%) & 50.00 & 54.00 & - \\
\hline
\end{tabular}

Biodegradable substances are those that naturally degrades or breaks down. In other words, natural agents such as sunlight, microorganisms, water, ozone, and others cause this decomposition, turning them into organic manure. Example: food waste, paper, dead plants, wood, etc. [13]. Non-biodegradable compounds are those that take a long time to degrade. Certain goods cannot decay because of how they are processed, and they do not occur naturally. As a result, they affect our environment when they remain in the ecosystem for a long time without getting decomposed. Example: plastic, glass, ceramics, metal [13].

Hazardous waste is distinct from other wastes because it cannot be disposed of in the same manner as other by-products of our daily lives [14]. They can be found in different physical states such as gaseous, liquids, or solids. Treatment and solidification processes can be needed depending on the physical condition of the waste. In our case, plastic is this type of waste. Plastic cannot biodegrade; it breaks down into smaller pieces. Toxic chemicals leach out of plastic and are found in nearly all of us' blood and tissue. Burning of plastics can release dioxins, which are most harmful to human organisms. Dioxin is a toxic organic chemical that contains chlorine, and it is produced when chlorine and hydrocarbons are heated at high temperatures. Inhaling dioxin or being exposed to its fumes can cause many deadly results.

\section{SEGREGATION OF SOLID WASTE STREAM}

Figure 5 shows the flow of waste, recyclables, and money in MSW management in Dhaka. In the Figure, it is noted that the recyclable waste flows from disposal sites to the waste pickers and then to the recyclable shop. On the other hand, the recyclable waste flows from door-to-door mixed waste collector to the recyclable shop.

Generally, the MSW is categorized into recyclable, biodegradable, and non-biodegradable wastes. Here is our suggested MSW flow that will make MSW management much more efficient and affect the environment less. Here, the waste flow has been established by different colours. Generally, the flow of recyclable waste has been established and the rest of the waste is separated into 'biodegradable wastes' and 'non-biodegradable wastes,' which needs to be sent to the respective collection sites in the area. From there, the wastes are taken to the municipal collection point. Non-biodegradable wastes are directly sent for treatment. On the other hand, biodegradable wastes go through a check to see if there is any non-biodegradable waste within them. If there is, they are sent for treatment too. Biodegradable wastes are sent to disposal sites or landfills. Additionally, the figure 6 , shows the segregation process of biodegradable and bio non degradable wastes separately. 


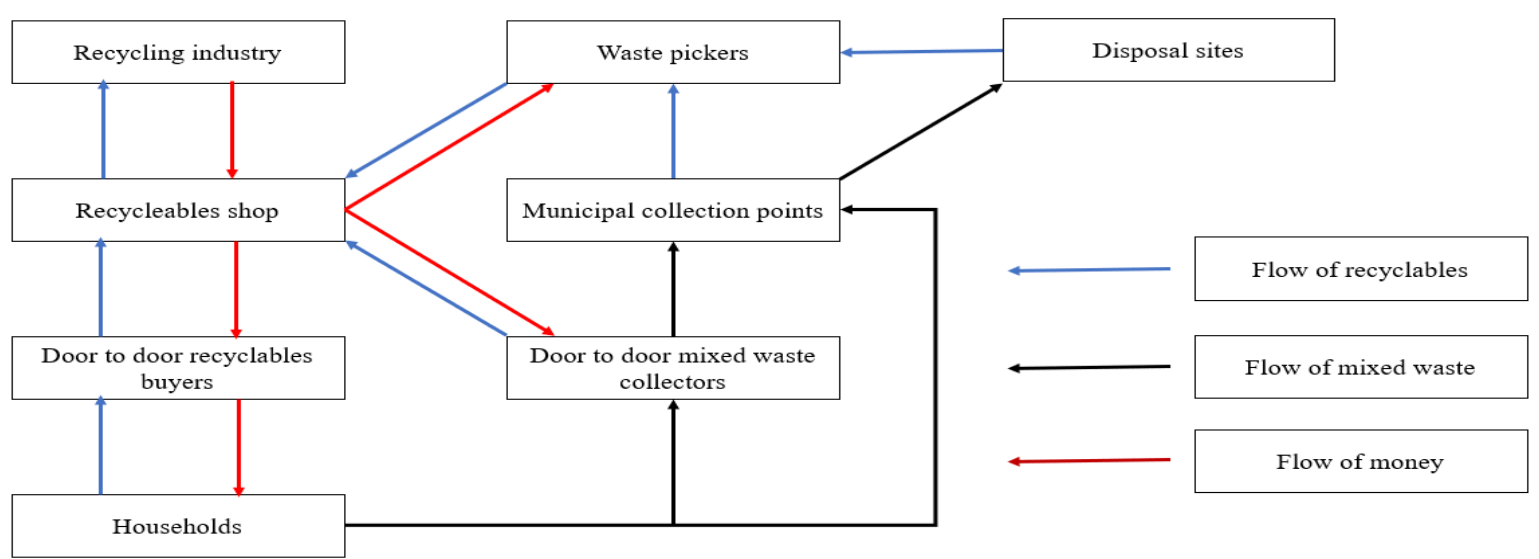

Figure 5: Flow of waste, recyclables and money in MSW management in Dhaka.

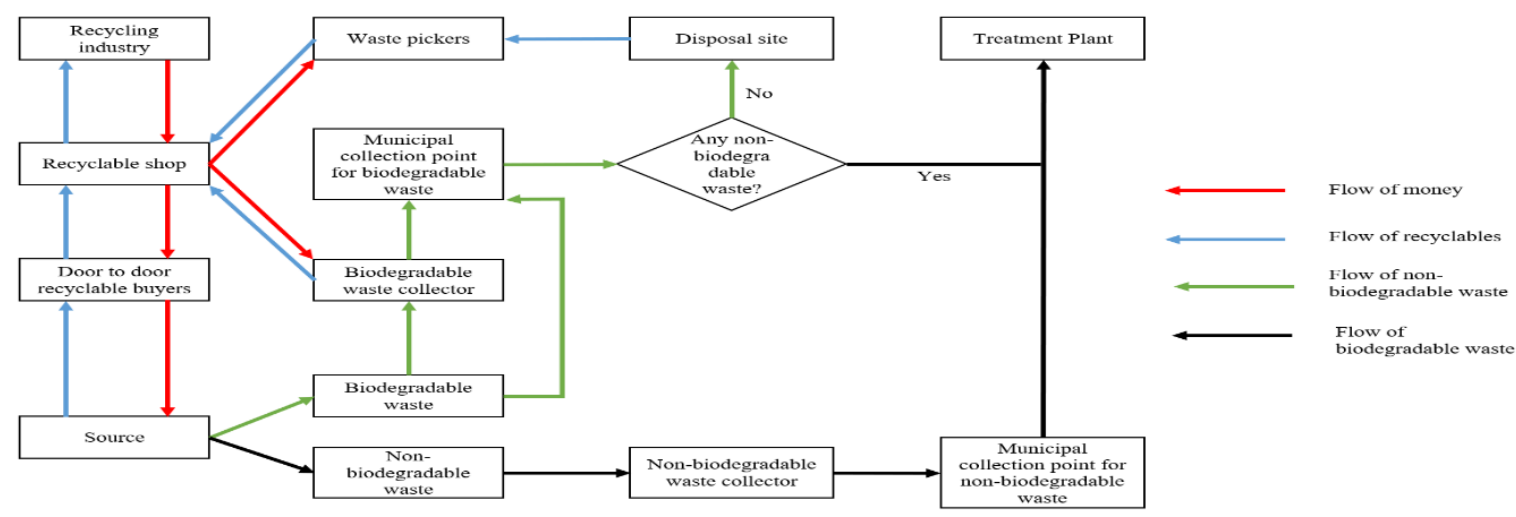

Figure 6: Suggested MSW flow.

\section{COLLECTION OF WASTE GENERATION DATA IN DHAKA CITY OF BANGLADESH}

The waste data of 50 houses for the month of April 2020, collected by the author for a local area of Dhaka City in Bangladesh and total manpower found to 250 and total amount of waste generated roughly around $498 \mathrm{Kg} / \mathrm{Day}$. Summarised information of the wastes is shown in Table 2. A typical model of waste collection and disposal system of house hold waste and wastes disposal of associated community-based organization (CBO) has been developed by the author and shown in Table 2.

1. Amount of wastes of 30 houses per day $=115.60 \mathrm{~kg}$.

2. Waste generation in one month $=115.60 \times 30=3450 \mathrm{~kg}$.

3. Total manpower found in 50 houses in one day 250 and in 30 days $=250 \times 30=7500$.

4. Per capita waste generation: $3450 / 7500=0.46 \mathrm{~kg}$ per day.

Note: There are 4-6 persons in a house.

\section{PLASTIC WASTE SEGREGATION MODEL FROM SOLID WASTE STREAM}

Recently one more effective and workable waste collection and segregation model has been developed as shown in figure 7 which now practised by a group of community personnel comprising 280 houses and total manpower around 1050 living that community under Saidpur City of Bangladesh. Figure 7 shows the separation process of both degradable and non-degradable wastes.

The physical system of plastic waste segregation model is developed in the Saidpur City of Bangladesh. Figure 8 shows the partial view of the of the plastic waste segregation system in Saidpur City of Bangladesh. The solid waste is randomly thrown in any roadside and the reiverside of Bangladesh [Figure 8(a)], however, people are generally seen to be engaged in segregating the wastes from the solid waste stream [Figure 8(b)]. Accordingly to the model doveloved in the Saidpur City of Bangladesh, the solid waste stream is systematically segregated to separte the plastic waste which is partially shown in the Figures 8 (c), (d), (e) and (f), respectively. 
Table 2: Day wise waste collection data of 50 houses in Dhaka city area of Bangladesh in 2020.

\begin{tabular}{|c|c|c|c|c|c|c|c|c|c|}
\hline \multirow{2}{*}{$S N$} & \multirow{2}{*}{ Date } & \multicolumn{7}{|c|}{$\begin{array}{l}\text { Composition of Waste } \\
\text { (in kg) }\end{array}$} & \multirow{2}{*}{$\begin{array}{c}\text { Amount } \\
\text { (in kg) } \\
\text { Total }\end{array}$} \\
\hline & & Kitchen & Paper & Plastic & Rubber & Glass & Metal & Others & \\
\hline 1 & 1 April & 2.50 & 0.20 & 0.20 & 0.20 & 0.06 & 0.14 & 0.24 & 3.54 \\
\hline 2 & 2 April & 1.90 & 0.15 & 0.25 & 0.30 & 0.05 & 0.09 & 0.20 & 3.00 \\
\hline 3 & 3 April & 1.90 & 0.10 & 0.20 & - & 0.05 & 0.05 & 0.40 & 2.50 \\
\hline 4 & 4 April & 2.00 & 0.10 & 0.20 & 0.20 & 0.05 & 0.05 & 0.45 & 2.55 \\
\hline 5 & 5 April & 2.00 & 0.16 & 0.25 & 0.30 & 0.20 & 0.10 & 0.40 & 3.25 \\
\hline 6 & 6 April & 2.10 & 0.15 & 0.25 & 0.25 & 0.05 & 0.15 & 0.50 & 3.60 \\
\hline 7 & 7 April & $1 . .90$ & 0.15 & 0.25 & 0.35 & 0.05 & 0.05 & 0.35 & 2.75 \\
\hline 8 & 8 April & 2.05 & 0.10 & 0.25 & 0.25 & 0.10 & 0.12 & 0.43 & 3.14 \\
\hline 9 & 9 April & 2.75 & 0.15 & 0.25 & 0.35 & 0.22 & 0.15 & 0.40 & 3.40 \\
\hline 10 & 10 April & 2.50 & 0.15 & 0.25 & 0.22 & 0.15 & 0.15 & 0.30 & 2.80 \\
\hline 11 & 11 April & 1.75 & 0.15 & 0.20 & 0.35 & 0.15 & - & 0.50 & 2.90 \\
\hline 12 & 12 April & 2.50 & 0.10 & - & - & - & 0.35 & 0.25 & 220 \\
\hline 13 & 13 April & 1.90 & 0.15 & 0.25 & 0.30 & 0.05 & 0 & 0.26 & 2.86 \\
\hline 15 & 15 April & 2.00 & 0.10 & - & 0.20 & 0.05 & 0.05 & 0.50 & 3.00 \\
\hline 16 & 16 April & 1.80 & 0.15 & 0.25 & 0.30 & 0.12 & 0.14 & 0.60 & 3.12 \\
\hline 17 & 17 April & 2.15 & 0.16 & 0.24 & 0.25 & - & - & 0.56 & 3.15 \\
\hline 18 & 18 April & 2.75 & 0.15 & 0.25 & 0.30 & 0.05 & 0.05 & 0.25 & 2,85 \\
\hline 19 & 19 April & 1.25 & 0.15 & - & 0.10 & - & - & 0.43 & 2.78 \\
\hline 20 & 20 April & 2.65 & 0.32 & 0.25 & 0.30 & - & - & 0.60 & 3.40 \\
\hline 21 & 21 April & 2.50 & 0.14 & 0.25 & - & 0.11 & 0.22 & 0.23 & 2.99 \\
\hline 22 & 22 April & 2.67 & 0.14 & - & 0.3 & 0.10 & 0.35 & 0.40 & 3,22 \\
\hline 23 & 23.April & 2.57 & 0.13 & 0.24 & 0.25 & 0.15 & 0.05 & 0.32 & 3.14 \\
\hline 24 & 24 April & 1.77 & 0.15 & 0.25 & 0.36 & 0.25 & - & 0.34 & 3.40 \\
\hline 25 & 25 April & 2.55 & 0.17 & 0.22 & 0.25 & 0.25 & 0.15 & 0.25 & 3.10 \\
\hline 26 & 26 April & 2.00 & 0.15 & 0.25 & 0.31 & - & - & 0.55 & 3.45 \\
\hline 27 & 27 April & 2.50 & 0.12 & 0.25 & 0.22 & 0.23 & 0.35 & 0.46 & 3.15 \\
\hline 28 & 28 April & 1.90 & 0.15 & 0.23 & 0.33 & 0.15 & - & 0.35 & 3.14 \\
\hline 29 & 29 April & 2.03 & 0.11 & - & 0.13 & 0.22 & - & 0.35 & 3.12 \\
\hline 30 & 30 April & 2.10 & 0.15 & 0.25 & 0.22 & - & 0.12 & 0.36 & 3.30 \\
\hline \multicolumn{2}{|r|}{ Total } & 72.10 & 5.40 & 6.00 & 6.60 & 6.9 & 6.3 & 12.3 & 115.60 \\
\hline
\end{tabular}

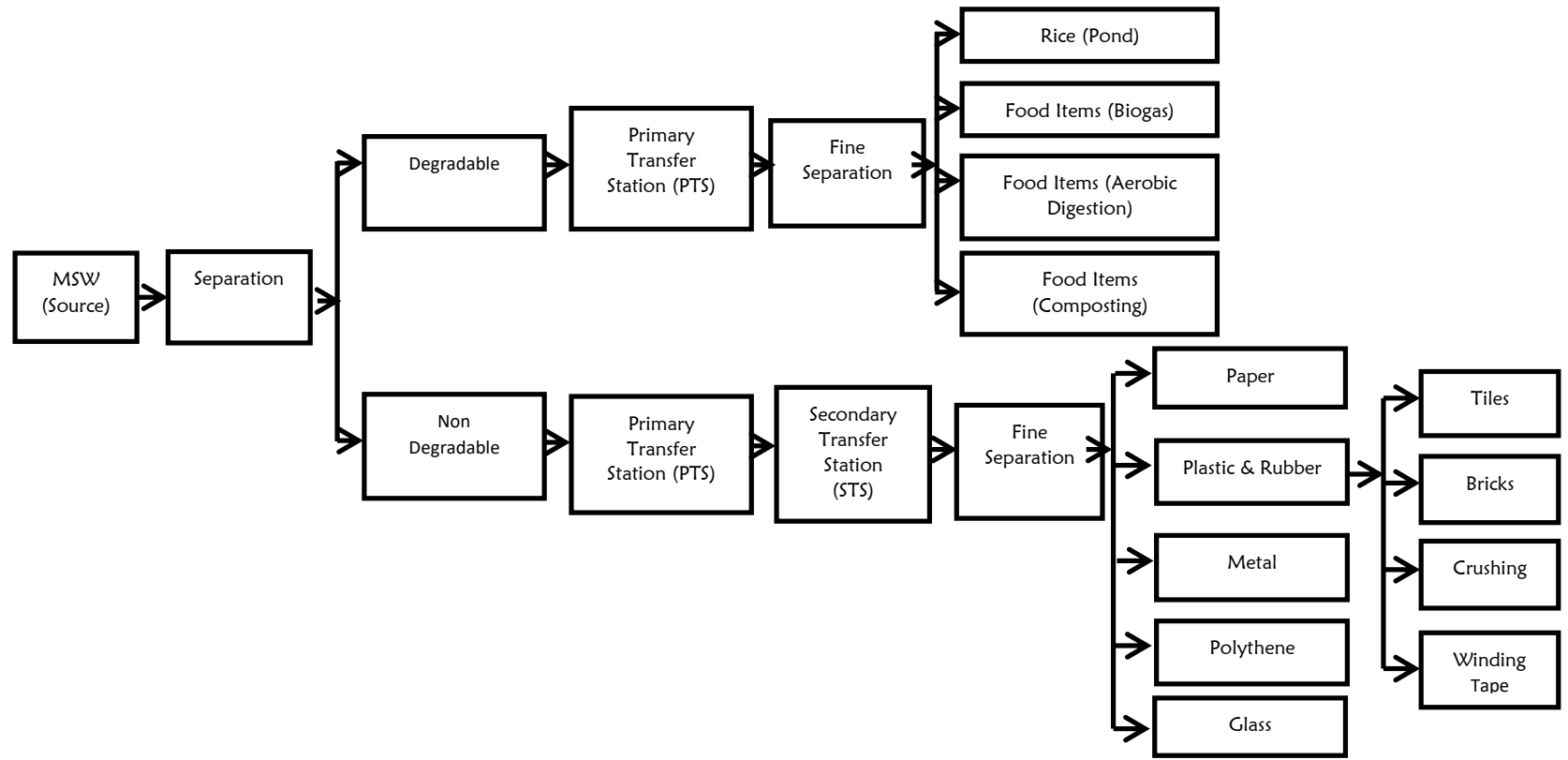

Figure 7: Plastic waste segregation model from solid waste stream. 


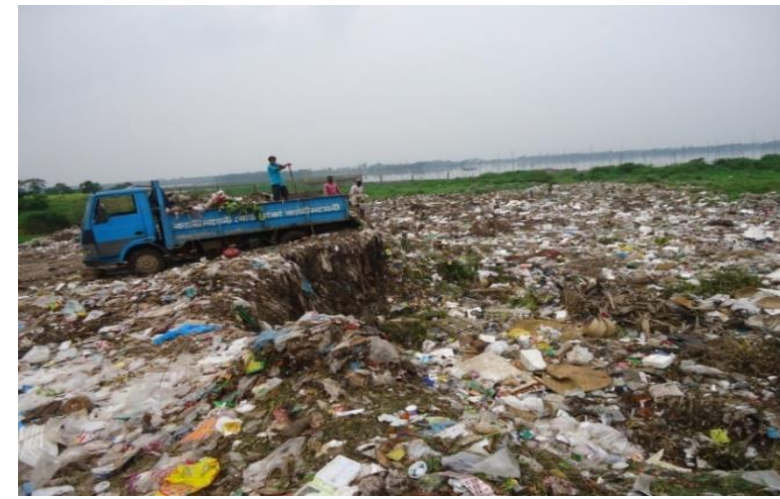

(a) Solid waste stream filling

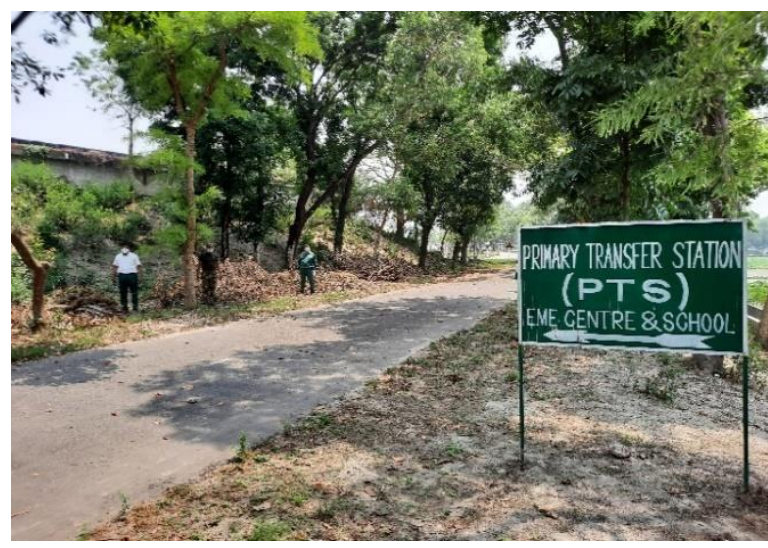

(c) Primary transfer station (PTS)

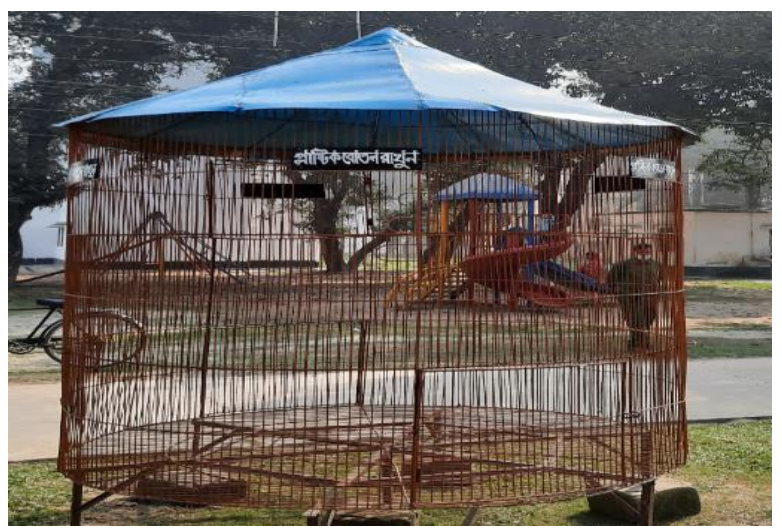

(e) Plastic waste cage

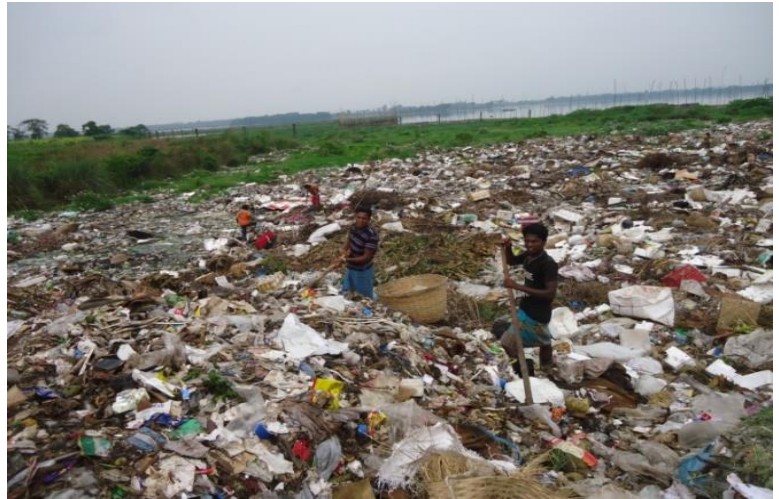

(b) Waste segregation randomly from solid waste stream

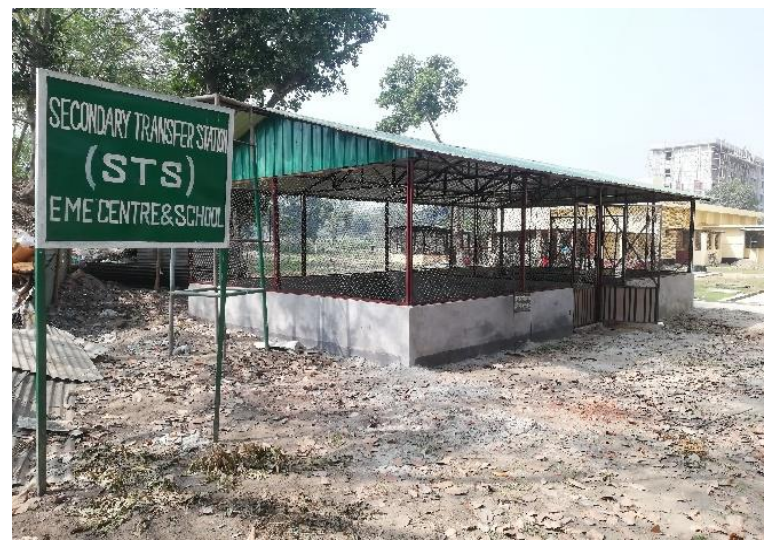

(d) Secondary transfer station (STS)

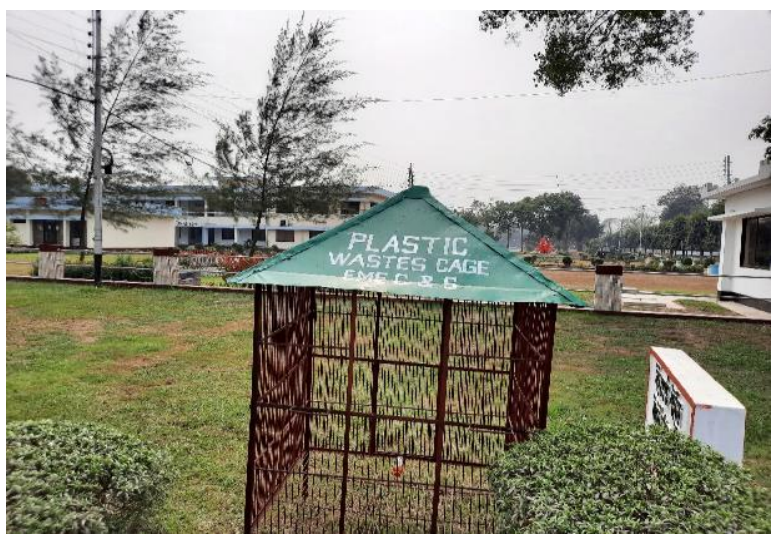

(f) Plastic waste cage

Figure 8: Partial view of the plastic waste segregation system in Saidpur City of Bangladesh.

\section{CONCLUSIONS}

The segregation of plastic waste from solid waste stream has been analyzed for Bangladesh perspective. The following conclusions may be drawn from the present analysis.

1. MSW management is essential for a developing country like Bangladesh as its generation is increased coupled with an increase in population growth. Nonetheless, management of the waste varies from country to country including its segregation process. Once we cannot avoid the waste we should make endeavour as how can we turn waste into a good source of income and energy source rather than a burden. We have developed a step towards turning the waste beneficial for us by separating it at the source as a more efficient management 
method. For a country like Bangladesh, CBO (Community Based organization) waste separation and management are more effective due to financial and land constraints.

2. The municipal solid waste (MSW) management includes recycling, composting, disposal and waste-to-energy e.g. incineration. Waste management is not possible with a single method. For this reason, a hierarchy of ranking strategy is also developed for municipal solid waste management. The waste management hierarchy consists of various levels: arranged from most preferred to least preferred methods based on their environmental soundness e.g. source reduction, reuse; recycling or composting; energy recovery; treatment and disposal.

3. Unfortunately, general people of Bangladesh are not much aware of the consequence of waste dumped as Landfills. As we cannot avoid the waste, our effort has to be continued to make best use of wastes, with waste minimization strategy e.g. reduce, reuse and recycle (3R Strategy). Once we all will be motivated then wastes will no longer be a problematic issue. We must seek for the action plan as how best we get benefits out of the MSW. It is only possible, if we can separate the waste at its source and technically manage it as a resource not considering it as burden. Technical Management Plan of waste for resource recovery can lead to a substantial reduction in the overall waste quantities requiring final disposal in Bangladesh and as well as in the globe.

\section{REFERENCES}

1. UN Data. (2012). Country Profile: Bangladesh. [Online]. Available: http://data.un.org/ [11 March, 2021]

2. The study on Solid Waste Management in Dhaka City: Clean Dhaka Master Plan, JICA Final Report for Dhaka City Corporation, GE JR 05-017, March 2005.

3. Samah, M. A. A., Manaf, L. A., Aris, A. Z. \& Sulaiman, W. N. A. (2011). Solid waste management: Analytical hierarchy process (AHP) application of selecting technology for Malaysia. Current World Environment (CWE) Journal, 6, 1-16.

4. Ahammed, A. A. (2013). Selection of the most appropriate package of solar home system using analytic hierarchy process model in rural areas of Bangladesh. Renewable Energy, 55, 6-11.

5. Marie, M. (2009). Energy system analysis of waste-to-energy technologies. PhD Thesis, Alborg University, Denmark.

6. State of Practice for Emerging Waste Conversion Technologies, Final Report of US Environmental Protection Agency (EPA), EPA/600/R-12/705, October 2012.

7. Enayetullah, I., Sinha, A. H. M. \& Akhter, S. S. (2012). Urban solid waste management scenario of Bangladesh: Problems and prospects. Waste Concern Technical Documentation,102-110.

8. Bruce, J. C. \& Marc, J. R. (2010). Economic feasibility of a plasma arc gasification plant. Proceedings of the $18^{\text {th }}$ Annual North American Waste-to-Energy Conference, NAWTEC18, 11-13, Florida, USA.

9. Islam, K. M. N. (2017). Municipal solid waste to energy generation: An approach for enhancing climate cobenefits in the urban areas of Bangladesh. Renewable and Sustainable Energy Reviews, 81(2), 2472-2486.

10. Shiri, N. V., Kajvana, P. V., Ronjon, H. V., Pais, N. L. \& Naik, V. M. (2015). Processing of waste plastics into building materials using a plastic extruder and compression testing of plastic bricks. Journal of Mechanical Engineers and Automation (JMEA), 5(3-B), 39-42.

11. Chiemchasisri, C., Charnnok, B. \& Visvanathan, C. (2010). Recovery of plastic wastes from dumpsite as refuse derived fuel and its utilization in small gasification system. Elsevier Bio resource Technology, 101, 1522-1527.

12. Janajreha, I., Adeyemia, I. \& Elagroudy, S. (2020). Gasification feasibility of polyethylene, polypropylene, polystyrene waste and their mixture: Experimental studies and modeling. Sustainable Energy Technologies and Assessments, 39, 100654.

13. Topacio, A., Arkuino, R. C., Romano, K. V. \& Abutin, J. C. (2018). Development of hydrophobic composite roof tiles utilizing recycled plastic materials. Material Engineering and Development, 65-72.

14. Gangaraju, P. M., Ramayya, K.V., Praksh, P. B., Basha, S. K. G. \& Kumar, B. S. (2020). Making of plastic tiles using waste plastic collected from fertilizer bags, plastic wires and waste tyre tubes (Polypropylene, Polyurethane, Thermoplastic and Polyester). International Journal of Advanced Science and Technology, 29(5), 7657-7662. 